\title{
Examining leaders' orientations to structural constraints: Turkey's 1991 and 2003 Iraq war decisions
}

\author{
Esra Cuhadar ${ }^{\mathrm{a}}$, Juliet Kaarbo ${ }^{\mathrm{b}}$, Baris Kesgin ${ }^{\mathrm{c}}$ and Binnur \\ Ozkececi-Taner ${ }^{\mathrm{d}}$ \\ ${ }^{a}$ Department of Political Science, Bilkent University, Bilkent, Ankara 06800, Turkey. \\ ${ }^{b}$ Politics and International Relations, School of Social and Political Science, University of Edinburgh, \\ 4.21 Chrystal Macmillan Building, 15a George Square Edinburgh, EH8 9LD, UK. \\ 'Susquehanna University, 514 University Ave. Selinsgrove, PA 17870, USA. \\ ${ }^{\mathrm{d}}$ Department of Political Science, Hamline University, 1436 Hewitt Avenue, St. Paul, MN 55104, USA.
}

Explanations of states' security decisions prioritise structural - systemic, institutional and cultural - constraints that characterise foreign security decisions as a function of external/international, domestic/institutional, or normative/cultural factors. By examining Turkey's 1990-1991 and 2003 Iraq war decisions systematically, we problematise this prioritisation of structure, and we investigate the dynamic relationship between structural constraints and leaders in their decision-making environments. In these cases, while the structural constraints remain constant or indeterminate, the decision outcomes and the decision-making process differ significantly. Our findings, based on structured-focused comparison, process tracing, and leadership trait analysis, suggest that the leaders' personalities and how they react to constraints account for this difference and that dependence on only one set of factors leads to an incomplete understanding of security policies and international politics. We contribute to the broader understanding of leaders' personalities by suggesting that self-confidence and cognitive complexity are the key traits distinguishing leaders' orientations towards structural constraints.

Journal of International Relations and Development (2017) 20, 29-54.

doi:10.1057/jird.2014.31; advance online publication, 20 February 2015

Keywords: foreign policy; Iraq wars; leadership trait analysis; political personality; Turkey

In 1990-1991 and 2003, Turkey faced critical foreign policy choices concerning its neighbour, Iraq. In both cases, Turkey was pressured by the United States to support the US-led military action against Iraq. This pressure accompanied by promises of economic rewards from an important ally had to be balanced with concerns of instability that the military interventions would create - instability both across and within Turkish borders. In the first Gulf War, president Turgut Özal steered Turkey through controversial decisions, including the closing of the Turkish-Iraqi oil pipeline and the deployment of the US troops in Turkey. In the second Gulf War, 
Recep Tayyip Erdoğan, upon assuming power as prime minister during the decisionmaking process, was faced with questions of whether or not Turkey would allow the stationing of the US troops on its soil and grant over-flight rights. Both leaders supported cooperation with the US requests, but faced significant domestic opposition. Özal dominated the decision making in the first Gulf War, even though he had no specific constitutional authority to do so, and he engineered Turkish cooperation with the US-led military offensive against Iraq. Erdoğan, on the other hand, delegated authority and bungled a parliamentary vote that resulted in the rejection to the stationing of the US troops and the preclusion of a Northern front in the invasion of Iraq. Both episodes were significant junctures in the Turkish-US relations.

In this study, we argue that foreign policymaking involves a dynamic relationship between political leadership as agency and the international, institutional and cultural constraints as structure. Throughout, we use the term 'structure' as the context in which action takes place; it not only limits but also shapes and propels behaviour. By 'agency', we mean the role of humans in the decision-making process. We illustrate the dynamic structure - agency interaction in the Turkish decision-making context analysing the 1991 and 2003 Iraq war decisions. These cases are especially suitable for the purpose of our argument because although structural constraints were similar or indeterminate between Turkey's Iraq war decisions, the processes and choices were very different. This, we conclude, is indicative of the dynamic relationship between agency and structure. Specifically, we see two leaders, Özal in the first Iraq war and Erdoğan in the second Iraq war, with very different orientations towards structural constraints. These different orientations stem from certain personality traits, which influence both the process and the outcome of these critical decisionmaking episodes in Turkey's foreign policy.

\section{International and domestic structural explanations in security policy}

Structural explanations of security decisions, at both the international/systemic and the internal/domestic levels, are familiar to all students of international politics (Mintz and DeRouen 2010). From a neo-realist focus on anarchy and distribution of power (e.g. Waltz 1979; Gilpin 1983) to liberalism's expectations on the constraining factors of economic interdependent structures and international regimes (e.g. Keohane and Nye 1977; Krasner 1983), security policy is seen as a product of international pressures faced by states and their leaders. System-level constructivism also focuses on role structures (e.g. Wendt 1999) and normative structures (e.g. Finnemore and Sikkink 1998) to explain state behaviour according to the logics of appropriateness and constructed expectations of self and other.

Other constructivists look inside the state at the domestic/societal level and point to cultural norms and values, operating as structures of constraint on leaders and foreign policy (e.g. Berger 1998). Similarly, the cultural explanation of democratic 
peace focuses on societal norms and values that encourage peaceful means of conflict resolution when democratic states are dealing with other democracies who hold similar liberal values (Owen 1994). The institutional explanation of democratic peace stresses the role of institutional structures and the constitutional checks and balances that tie the hands of leaders through accountability to a more peaceful public (Russett 1993). Both rational choice theories of domestic costs (Bueno de Mesquita et al. 2003) and neo-classical realism's conception of the executive who must bargain with domestic political actors to extract resources in order to respond to international pressures (Lobell et al. 2009) also see political-domestic structures as limits on security policy.

Other institutional factors can constrain leaders. Government structures that create multi-party coalitions, for example, put multiple actors, or 'veto-players', in control of state policy. Multi-party governments can bog down decision making and create fragmented policy and excessive compromises; coalition governments may be more vulnerable to junior party influence and inter-party politics (e.g. Palmer et al. 2004; Özkeçeci-Taner 2005, 2009; Kaarbo 2012). In addition, decision-making rules, legal provisions as provided by the constitution (i.e. which decisions need to be made or approved by the parliament), different institutional arrangements that lead to the formation of different decision units, the relationship between the executive and the legislature, as well as within party disagreements can create further structural constraints on foreign policymaking.

Many of these issues become particularly complicated when the executive cannot make a decision such as 'declaration of war' or 'sending troops abroad' by itself or without the approval of the parliament (Hänggi 2004). In this regard, certain legal provisions, parliamentary opposition, and inter/intra-party factionalisation may limit the ease and speed of decision-making processes in both single and multi-party cabinets. Prime ministers (or cabinets) try to avoid taking an issue to the parliament if there is a chance that the bill, or the government, would be challenged by opposition parties or party backbenchers in the parliament. Similarly, they may simply wait until it becomes possible for them to promote consensus-based policies (LeBlang and Chan 2003; Wagner 2006).

Overall, many approaches to security policy emphasise the constraints imposed on political leaders by various structural forces. This literature underemphasises the role of the political leadership and does not examine how different leaders view national goals, interpret international, institutional and cultural constraints, or how they try to achieve their foreign policy objectives. Some leaders may indeed challenge structural constraints or be less open to incoming information in order to maintain their positions and divert attention from more disturbing issues (Hermann and Kegley 1995). In sum, leaders are not determined by structures, but instead interact with them as security policies are made. Although importance of both the context of structural constraints and the characteristics of leaders has been recognised (e.g. Giddens 1984; Dessler 1989; Carlsnaes 1992; Bueno de Mesquita et al. 2003; 
Chiozza and Goemans 2011), research is still largely silent on the question of how structural constraints are shaped and interpreted by leaders and whether or not all agents are equally constrained or empowered by structures. We agree that 'a major impediment to the development of adequate explanation and prediction in the study of international relations and foreign policy is the failure by many academics in the field to treat seriously the role of psychology factors in individual decision making and intergroup relations' (Goldgeier 1997: 137).

\section{Leaders' orientations towards structural constraints}

Decision makers are the central agents in the foreign policy-making process. Presidents and prime ministers are the leaders (in democratic states) that face international and domestic structures that may constrain their actions and choices. Yet, they also interpret, construct and shape these structures. Key to this relationship is their orientation towards constraints: leaders vary in how they respond to their environments. Some confront structural barriers and pressures; others defer to or work within them. Leaders' orientations to structures are based on key personality differences.

Leadership Trait Analysis (LTA) is one of the most prominent approaches to the study of political leaders. This framework, developed by Hermann, integrates decades of her research on the role of personality characteristics in foreign policy (e.g. Hermann 1980, 1984, 1987, 2003). In this approach, personality is conceptualised as a combination of seven traits: belief in ability to control events, conceptual complexity, need for power, distrust of others, in-group bias, self-confidence, and task orientation. LTA has been used to study the personalities of many leaders, including the US presidents, British prime ministers, sub-Saharan African leaders, and heads of international organisations. This research suggests that these personality traits indeed link systematically to leaders' decision-making behaviours and foreign policy choices.

The LTA framework is particularly useful for investigating the Turkish leaders' reaction in the Iraq wars. The framework conceptualises specifically how leaders differ in their reaction to structural constraints. Unlike other approaches (e.g. operational code research), LTA captures leaders' styles of interacting with others, rather than the content of leaders' beliefs. According to Hermann, an LTA-based personality profile links systematically to a leader's propensity to challenge or respect constraints in their environments, their openness to information and advice, the structure of their advisory systems, the quality of the decision-making process, and the policies that leaders choose for their country or organisation. Previous research supports these links (e.g. Hermann 2003; Kille and Scully 2003; Dyson 2006; Schafer and Crichlow 2010). Hermann (2003) suggests that the seven traits combine in particular ways to produce specific behaviours. Leaders who have a high 
belief in their ability to control events and a high need for power, for example, are expected to challenge constraints. Conceptual complexity and self-confidence are related to and predict leaders' openness to information.

Thus, the advantage of using the LTA framework for investigating agent structure relations is that it provides specific expectations regarding which characteristics of leaders matter and how. In other words, leaders with different traits are expected to relate to their context, institutional setting, costs and benefits of various policy options, and other agents in theoretically meaningful and predictable ways. Furthermore, the LTA approach provides a reliable, systematic, and comparative method for assessing agent characteristics.

\section{Method of investigation: case studies and content analysis}

We combine structured-focused case comparison (George and McKeown 1985; Mahoney 2004) and process tracing (Checkel 2008; Bennett 2010) with at-adistance content analysis (Schafer and Walker 2006). With this mixed-method approach, we situate personality profiles of political leaders in their context, comparing the contexts in a structured-focused fashion, through in-depth process tracing of decision making. We examine four specific cases; each case is an occasion for decision, defined as an instance to which a decision unit has to react (Hermann et al. 2001). There are usually numerous occasions for decision as governments respond to policy situations and this was true for Turkey in both Iraq wars. For the purposes of this article, we identify two critical occasions for decision for each time period and we analyse how political agents (leaders) interacted with structures in a detailed tracing of the decision-making process. We examine the cases specifically for similarities and differences in terms of the operative structural constraints. These cases are 'crucial in the strongest sense' (Gerring 2007: 232) because they are very similar to each other with the exception of leaders' personalities that a comparative study of them will provide 'the strongest sort of evidence possible in a nonexperimental setting' (Gerring 2007: 232) to confirm or disconfirm our arguments regarding the dynamic relationship between structural constraints and leaders in their decision-making environments. Evidence for the comparative case studies comes from descriptive accounts of the decision-making process written by journalists, diplomats, and other scholars and from semi-structured interviews that we conducted in July and August 2013. The primary agents for this analysis are Turgut Özal (for the first Iraq war) and Recep Tayyip Erdoğan (for the second Iraq war).

Özal was the Turkish prime minister (1983-1989) from the Motherland Party, and then served as president (1989-1993). Erdoğan became the Turkish prime minister in March 2003, in the middle of decision making regarding the Iraq war. He was, however, head of the ruling Justice and Development Party throughout this period 
and his eventual assumption of the prime ministership was expected. These leaders were certainly not alone in Turkish foreign policymaking, but they were central.

Prime ministers are typically regarded as one of the three actors in a 'tripod' that directs Turkish foreign policy (Makovsky and Sayar1 2000). As the head of the party that controls a majority (or the largest number of seats) in the parliament, the prime minister has the constitutional authority to direct foreign policy through the cabinet (the council of ministers) and is generally very influential in both processes and outcomes (Makovsky and Sayarı 2000). The foreign ministry and the military are also considered important actors in foreign policy. Compared with other democracies, the Turkish military is much more active in governance, as it has intervened in decisions and in the removal of civilian governments (Makovsky 1999). The main institution through which the military has influenced policymaking is the Milli Güvenlik Kurulu (MGK), Turkey's 'national security council'. Composed of military and civilian members (including the president, prime minister, and foreign and defence ministers), it serves as an advisory body in security-related matters.

The presidency in Turkey is typically viewed as a symbolic position and many presidents have interpreted their role as one that is 'above politics'. The 1982 constitution certainly strengthened the position of the president and made the powers of the president, also with regard to the foreign policy domain, more important during weak governments (Özcan 2008: 153); the president is considered to be the head of the state, and therefore expected to represent the state, as opposed to the government. This differentiation means that the president does not have to, nor is expected to, get involved in party politics. Some presidents, however, have played a much more activist role and Özal's presidency in particular has prompted scholars to include the president as a potentially important player in foreign affairs. Arguably, presidents Süleyman Demirel and Abdullah Gül represent similar activism. In contrast, Ahmet Necdet Sezer, the president before Gül, did not. The parliament is considered a secondary actor in Turkish foreign policy, although Article 92 of the constitution gives the parliament the authority for foreign troop deployment in Turkey and for sending Turkish troops to other countries. Finally, Turkish leaders are accountable to the public in democratic elections; however, elites are seen as having great capacity for managing public pressures in the area of foreign policy (Makovsky and Sayarı 2000). In sum, president Özal and prime minister Erdoğan were key agents in the Iraq decisions, although they faced other agents and structural constraints on their ability to make Turkish foreign policy. ${ }^{1}$

The personality profiles of Özal and Erdoğan are based on the LTA content analysis scheme. For the LTA coding, it is assumed that the more frequently leaders use certain words and phrases when they speak, the more apparent and salient such content is to them and the more it reflects underlying personality traits (Hermann 2003). Coding is quantitative and employs frequency counts taking the word or phrase as the unit of analysis. LTA profiles are now produced with automated machine-coding using ProfilerPlus, a language parsing software programme 
developed by Social Science Automation (SSA). ${ }^{2}$ The programme determines the percentage of particular words and phrases used by the leaders based on the length of the text. ${ }^{3}$ The percentages for any leader can be compared with those of 284 world political leaders and a subset of 46 leaders from the Middle East. Through such comparisons, it becomes possible to determine whether the particular leader is high, low, or average on a trait (Hermann 2003). Our primary focus in this paper is comparing the leadership traits of Özal with Erdoğan's to understand the different ways in which these leaders interacted with structures.

For this study, we confined the text coded to the time period before the decisions under investigation: for Özal, from 16 March, 1987 to 7 January, 1991; for Erdoğan, from 28 August, 2001 to 9 March, 2003. Although this is a shorter time period for Erdoğan, it was important to restrict this study to these periods because leaders' styles may change over time (Hermann 2003) and it would be inappropriate to use text spoken after the cases to capture Özal's and Erdoğan's personality traits. For Özal, we analysed 44,346 words in 47 documents; for Erdoğan, 9,317 words in 33 documents, all drawn from interviews with domestic and international media as well as from the leaders' spontaneous statements at press briefings. ${ }^{4}$ The contents analysed were limited to foreign policy issues. The content analysis was conducted in English using ProfilerPlus, Version 5.8.4.

Although LTA and other at-a-distance assessments have become more reliable with machine-coding, they continue to face a central question of validity: do the words of leaders truly reflect their personal beliefs and personality characteristics? This question revolves around authorship, audience effects and deception, temporal stability, and language differences. In this study, we address these issues by using only interviews and other spontaneous material and not prepared speeches. We combine the texts across different audience types (i.e. domestic and international), and assume that these leaders' characteristics can be meaningfully assessed in English (if the text was originally spoken in English) or in English translations. We build on previous scholarship and assert that leaders do have some control over their speech acts and that LTA can capture leaders' public personalities (if not their private ones), which matter more for explaining their decision-making style and foreign policy choices. ${ }^{5}$ We also assess the validity of these profiles by pairing them with case studies to see if the personality variables play out in the decision-making processes in theoretically meaningful ways; if they do, we can have greater confidence that LTA is capturing what it purports to measure.

\section{Turkey's first and second Iraq war decisions}

\section{The 1990-1991 Iraq war and occasions for decisions}

When Iraq invaded Kuwait in August 1990, the UN Security Council convened within hours and unanimously adopted Resolution 660, demanding that Iraq 
withdraw from Kuwait immediately and unconditionally, and negotiate through peaceful means (Department of Public Information of the United Nations 1990: 167). The United States also demanded reinstatement of the Kuwaiti government, restoration of regional security and stability (Department of Defence 1992: 22). The United Nations followed with mandatory sanctions on Iraq, a shipping blockade, and an authorisation for member states to use all necessary means to end the Iraqi invasion. When Iraq did not comply, the military intervention of the US-led alliance began on 17 January, 1991. The war ended with the reinstatement of the Kuwaiti regime and the withdrawal of Iraqi forces on 26 February, 1991.

Throughout the crisis, Turkey, a neighbour of Iraq with a Muslim majority, sided with the United States. There were several important occasions for decision confronting the Turkish leadership (Oğuz 2005). These included the questions of (1) if the Iraq-Turkey oil pipeline should be closed and economic sanctions implemented; (2) if Turkish troops should be sent to join the coalition forces; (3) if the coalition military forces should be allowed to use Turkish soil to launch attacks on Iraq; and (4) if a second front should be opened via Turkey. Among these, the decisions to close the oil pipeline and the deployment of the US troops to Turkey to launch attacks across the Turkish-Iraqi border became the most pressing issues at the time. On both occasions, president Turgut Özal was not the only person who had the ability to commit the country's resources and had to work with others. Yet, Özal was very much involved in the decision-making process and acted as a prominent political actor.

\section{Closing of the oil pipeline}

The Kirkuk-Yumurtalık pipeline carried nearly half of Iraq's oil (Hale 2000). The US leadership requested Turkey to close the pipelines during the early days of the crisis. Özal asked the US president Bush to get a UN Security Council resolution to that effect. After the UN resolution was obtained on 6 August, 1990, an occasion for decision was created for Turkish decision makers. The major issue was whether or not the economic embargo should be implemented immediately and when the pipeline should be closed. The latter was especially important because the closing of the pipeline would be very costly for Turkey, albeit crucial for the successful implementation of the UN sanctions on Iraq.

In the end, the Turkish leadership agreed to close the pipeline in accordance with the Security Council resolution, but there was some disagreement between Özal and others concerning the timing (Efegil 2002). Initially, it seemed as if Turkey was going to adopt a wait-and-see approach and would not close the pipeline right away. The ministry of foreign affairs and prime minister Yıldırım Akbulut (from the same political party as Özal) stated that Turkey was not ready to impose economic sanctions against Iraq and that Turkey should wait for Saudi Arabia's reaction. If the Saudis declined to close their pipelines, the embargo would not be effective 
(Bush'tan Özal'a: Boru Hattını Kapatın 1990). Others, including the Turkish Armed Forces, suggested that Turkey would continue to 'adhere to its previous policy of remaining strictly aloof from Middle Eastern conflicts' (Hale 2000: 220). While these actors favoured a more cautious stance, president Özal's personal and often secret communications with president Bush continued.

The council of ministers meeting on 7 August, 1990, displayed the dominance of Özal as he made his preference clear and declared that he had already taken the relevant initiatives. Indeed, that very same day, Özal convened a small meeting with the state minister for energy, Mehmet Keçeciler, and ordered him to declare the pipeline closed (Oğuz 2005: 50-51). This announcement came as a surprise given that the decision was made without the knowledge of some very important decision makers, including the chief of staff Necip Torumtay, whose consent was required to make such a decision. Özal used the meeting of the council of ministers strategically and made the decision appear as if it were the government's decision. On 8 August, it was announced publicly that Turkey would suspend all commercial dealings with Iraq and close the oil pipeline from Kirkuk to Yumurtalık. ${ }^{6}$ As later reports indicate, Özal put pressure on cabinet ministers to agree with his initiatives, despite opposition from the ministry of foreign affairs, opposition parties in the parliament, and the military (Efegil 2002; Oran 2001).

\section{Allowing the US-led forces deployment in Turkey}

When the prospect of a military operation against Iraq became apparent, another important occasion for decision emerged. Turkey hosted several US military bases on its soil, and unlike the previous decision, this occasion for decision - whether or not to allow the US-led forces in Turkey to be deployed - necessitated the approval of the Turkish parliament. Article 92 of the Turkish constitution requires parliamentary approval for foreign forces on Turkish soil for war purposes or for Turkish territory to be used in a war situation. Interestingly, president Özal had already asked prime minister Akbulut to take the issue to the parliament even before a request to deploy military forces came from the United States. According to many, Özal was informed about the US plans to use the bases in Turkey in advance and wanted to ensure parliamentary approval before the issue became a divisive one within Turkey (Hale 2000; Efegil 2002).

The decision to bring the motion to the parliament created considerable disagreement among the ruling Motherland Party, the ministry of foreign affairs, and the chief of staff. The motion created tension because it was perceived as a war decision on a country that did not attack Turkey and as giving a 'green light' for the utilisation of the US bases in Turkey. However, similar to the first occasion for decision, president Özal was effective in using his influence over the prime minister and did not refrain from publicly criticising those who were reluctant, such as the chief of staff and military officials, the ministry of foreign affairs, and the opponents in the Motherland 
Party. However, unlike the first occasion, Özal could not act alone, given the constitutional structural constraints.

The situation became more tense when the US secretary of state Baker, on his visit to Ankara on 9 August, 1990, requested (1) the use of the US bases located in Turkey for an air campaign in Northern Iraq, (2) the movement of Turkish troops to the Turkish-Iraqi border to help deter Saddam Hussein from moving his troops to Southern Iraq, and (3) the dispatch of a Turkish battalion to Saudi Arabia to join the allied forces assembling there (Pertman 1990). Özal immediately authorised prime minister Akbulut and the cabinet to get the necessary parliamentary approval. The office of the prime minister prepared a memorandum asking the parliament to grant the government the power to send Turkish troops abroad and permit the stationing of foreign troops in Turkey. The ministry of foreign affairs was once again left in the dark. After intense parliamentary debates, a bill, which stated that the government requested 'permission' (not 'power') to declare war only 'in case of aggression against our country' was approved (Hale 2000).

Özal, finding the bill too restrictive and not operational, pushed further to persuade members of the parliament to approve an 'unconditional authorisation' that would give him control over the decision. He became personally involved, alongside the council of ministers, in preparing a new memorandum, in which he asked for more power for the government with regard to sending Turkish troops to foreign countries and allowing foreign forces to be stationed in Turkey. Despite the rejection and/or abstinence of 30 members of the ruling Motherland Party during the vote on the motion on 5 September, 1990, parliament gave permission to the council of ministers to send Turkish troops and to allow the stationing of foreign forces in Turkey. The limits and scope of such actions were to be determined by the government even if Turkey was not attacked (Oğuz 2005: 70; Journal of Proceedings of the Parliament [TBMM Tutanak Dergisi], 1 September 1990). Yet, the parliament rejected the government's request for permission to declare war (Hale 2000). Although the authoritative decision unit was not president Özal on this occasion, he was still extremely influential in the decision outcome and constantly challenged structural constraints.

\section{The 2003 Iraq war and occasions for decisions}

Following the 9/11 terrorist attacks, the Bush administration perceived the Iraqi regime as a threat to the US security. Iraq was, allegedly, equipped with weapons of mass destruction and, consequently, the US government began planning a military operation in 2002. The operation began on 20 March, 2003.

The US preference to open a Northern front via Turkey in the Iraq war became an important issue in Ankara in December 2002 and January 2003, only months after the newly elected Justice and Development Party ('Adalet ve Kalkınma Partisi', AKP hereafter) came to power. Although sympathetic to the US worries, the newly created government was hesitant to support the US initiative directly as many Turks saw a 
possible invasion of Iraq by the United States as nothing more than an act of aggression (Gözen 2005; Kapsis 2006). The US decision to invade Iraq, with or without Turkish support, proved to be the first major challenge for the new government that was largely inexperienced and wanting to please both the US government and the Turkish public. This would prove difficult as approximately 90 per cent of the Turkish public opposed the US intervention, seeing it as unlawful and unethical (Gözen 2005), and most Turks (86 per cent) were also against the stationing of the US troops in Turkey for the invasion (Özdamar and Taydaş 2012). The antiwar and anti-American sentiments among the Turkish population resulted from the nature of the ongoing US-Turkish negotiations and how the United States treated Turkey, as well as from Turkey's experience during the first Gulf War (Özdamar and Taydaş 2012). Public opinion mattered more than usually during this period, although it remained only one of the factors influencing Turkish leaders.

The rejection of the motion by the Turkish parliament on 1 March, 2003, is usually considered to be the critical event in Turkey's decision on the 2003 Iraq war. Yet, there were four important occasions for decision. These included: (1) the February 6 motion: if Turkey should authorise the United States to upgrade the US military bases in Turkey in preparation for the impending war; (2) the March 1 motion: if Turkey should allow the United States to station troops in Turkey as a base for a Northern front, (3) the March 20 motion: if the United States should be given over-flight rights; and (4) the October 7 motion: if Turkey should send its own troops to Iraq (Yetkin 2004: 100).

Among these, we focus on the second and the third occasion for decision, as they proved to be the most contentious. Although neither Recep Tayyip Erdoğan, who was not part of the cabinet during the initial stage due to legal constraints, ${ }^{7}$ nor Abdullah Gül had 'the authority to make a decision that cannot be readily reversed' (Hermann 2001: 48), both acted as prominent political actors on both occasions for decision. Following by-elections, Erdoğan was elected to the parliament on 9 March and he replaced Gül as prime minister on 14 March, 2003. Gül was appointed as the minister of foreign affairs the same day. Although these changes took place as negotiations about Turkey's involvement in the Iraq war were underway, Erdoğan, as head of the AKP and prime minister-to-be, was the leading figure from the very beginning of the process. According to Taydaş and Özdamar, 'Erdoğan acted as de facto prime minister and led the Iraq war talks with the United States, even though he had no formal powers. He tried to show the members of the party that he was, indeed, in charge' (2013: 234). The minister of foreign affairs during the time of the crisis, Yaşar Yakış, also confirmed that he and prime minister Gül consulted with Erdoğan on highly critical decisions concerning the crisis. ${ }^{8}$

\section{Deployment of the US troops in Turkey for a Northern front}

The first written request from Turkey was sent on 19 November, 2002, asking the Turkish government to allow the US personnel who were permanently based in 
Turkey to prepare the US bases for use during the war. Both the military officials and the foreign ministry bureaucrats completed a detailed report strongly recommending Turkey's support to the US-led coalition before the gathering of the MGK on 31 January. They criticised the indecisive attitude of the government and insisted that it should make a decision urgently (Yetkin 2004). Despite the MGK's green light to eventual participation in a military action against Iraq, the government refrained from making a clear decision. Prime minister Gül hoped to prevent war by visiting countries in the region and sending Turkish officials to meet with Iraqi officials to persuade Saddam Hussein to comply with the sanctions regime (Yetkin 2004). This was partly because he knew that he would have difficulty convincing his party members to vote in favour of a motion supporting the US deployment and opening a Northern front in the Iraq war (Yetkin 2004).

On 6 February, 2003, by a vote of 308 to 193, the Turkish parliament passed Resolution 759, giving power to the government to open a number of Turkish bases to the US specialists for war preparation. The motion represented the government's willingness to cooperate with the United States. Some parliamentarians adamantly rejected the claim that this was a 'blank check' of support for the US-led coalition. The government, however, was already in negotiations with the Bush administration regarding Turkish involvement in the war. In these negotiations, Turkey set forth a number of conditions for its involvement, including the deployment of defence capabilities at its border with Iraq to manage any refugee flow, the US economic aid to compensate for losses from the war, and a partnership with the United States in overseeing the distribution and recollection of sophisticated weapons to opposition groups in Northern Iraq.

The Turkish government and the US officials had an understanding that an agreement was in the making. The negotiations regarding a deal were almost concluded by the third week of February. Before a cabinet meeting on 24 February, 2003, foreign affairs minister Yaşar Yakış said that an agreement in principle, yet unofficial and not final, was reached on the political and military conditions of the US deployment, and only a few issues remained concerning the economic aid package. Turkey was to be offered US\$2 billion in aid and $\$ 24$ billion in loan provision (Bölükbaşı 2008). Turkey and the United States, however, were unable to reach a final agreement (Yetkin 2004).

Hesitant to put a motion to parliamentary vote and ask for delegation of power from the parliament to allow the deployment of the US troops in Turkey and the sending of Turkish troops to Iraq, especially without a written agreement, the AKP government received more pressure from the United States, despite major disagreements regarding the details of Turkey's involvement within the Turkish leadership (Yetkin 2004). Finally, the US administration asked the Turkish government to make a decision within 48 hours.

This pressure intensified further the divisions among policymakers in Ankara. Some cabinet ministers were in favour of the deployment of the US forces and 
Turkey's involvement in the conflict, although others were opposed to them. Although the MGK, the ministry of foreign affairs, and the Turkish Armed Forces were generally pro-deployment, president Necdet Sezer, most of the deputies in the parliament including the opposition parties, and the speaker of the parliament Bülent Arınç (AKP) were against it (Yanatma 2008). The newly elected AKP government, and especially Gül as temporary prime minister, were reluctant to take responsibility. Gül wanted to diffuse accountability by emphasising that the military favoured direct involvement (Yetkin 2003, 2004) and he sought public affirmation from the military, which could help the government share responsibility for a war decision. Tellingly, before sending in the motion asking for deployment, the cabinet decided to wait until the MGK meeting on 28 February, 2003, with the expectation of a strong recommendation from the military. The military, on the other hand, was waiting for a political decision and refrained from announcing an opinion publicly (Yetkin 2004; Bölükbaş1 2008).

The AKP leader Erdoğan was conflicted about the decision. Although he was sensitive to the overwhelming public opposition and the reservations within his own party, he felt that the newly elected Islamic-associated government could not risk going against the United States, Turkey's most important long-standing ally. 'In the end, Erdoğan chose the middle ground and gave the impression that he did not strongly support either option. He asked the government to move with negotiations and preparations for the war, but in public, he did not strongly support the motion' (Taydaş and Özdamar 2013: 235).

Erdoğan and Gül decided to send a motion to the parliament. The motion asked the parliament to allow 62,000 US troops (also 255 warplanes and 65 helicopters) to be stationed in Turkey as well as to grant the right for Turkey to deploy 40,000 troops in coordination with the United States in Northern Iraq (Robins 2003a). The parliament voted on the motion on 1 March, 2003, only to reject it. Although the motion gained a numeric majority (264 to 250), it failed to receive the simple majority of all legislators because of 19 abstentions. By all accounts, the party leadership was surprised at the outcome (Yetkin 2003; Kesgin and Kaarbo 2010; Taydaş and Özdamar 2013).

\section{Opening of Turkish air space}

On 14 March, 2003, five days after winning a by-election, Erdoğan became prime minister. Even before the changes in the cabinet, the AKP leadership had agreed to present a new motion to the parliament and pursue it with great vigour when the right time came (Robins 2003a). The argument this time was that the new bill should not commit Turkey directly to participate in the Iraq war, but allow the United States to use its bases in Turkey.

The new motion was sent to the parliament for a March 20 vote, as Article 92 required. Unlike the March 1 motion, two leaders were more proactive on this occasion: chief of staff Hilmi Özkök and the AKP leader and new prime minister 
Erdoğan. Özkök declared publicly that the military supported the government's position (Yetkin 2004: 186). According to the military, Turkey should not be left completely outside of the events in Iraq and it should have a say in re-shaping the new Iraq. For Özkök, by just wishing the war did not happen and doing nothing, Turkey would be hurt (Balbay 2004). Such a clear and strong declaration by the military was influential in the second decision.

Erdoğan also took important extra measures before the parliamentary vote. Tellingly, he did not reappoint Ertuğrul Yalçınbayır, who eventually voted against the bill, to the new cabinet (Kesgin and Kaarbo 2010). Moreover, there were several 'closed-door' meetings that Erdoğan held with the AKP deputies before the vote. The bill was approved on 20 March, following a 332 to 202 vote and one abstention. This result gave the government the power to grant the United States over-flight rights to conduct bombing missions and to send special forces to Northern Iraq to engage Iraqi forces.

\section{Structural factors in the 1991 and 2003 Iraq war decisions}

On these occasions for decisions, structural constraints were either very similar or indeterminate. For both cases, Turkey's most important strategic ally, the United States, offered rewards and put pressure on Turkey to secure Turkish cooperation in the military conflicts. The threat of a destabilised Iraq and what that would mean for Kurdish aspirations for independence and for refugees into Turkey were also operative in both cases and decision makers had to decide if it was better to be involved and have some post-conflict influence on Iraq, even if they opposed the invasions. The economic costs on Turkey of a war, despite promises of off-setting aid from the United States, were additional constraints that Turkish leaders had to consider in 1991 and 2003.

Certainly, the international structure differed in other ways across these time periods. In 1991, the Cold War had only just ended. The Soviet Union still existed, it was an ally of Iraq, and was an important factor in the US and the UN decision making. In 2003, the bipolar international structure had clearly given way to the military hegemon, the United States. Arguably, Turkey was more constrained by the international structures in 1991. As a middle power, it was clearly dependent on the United States during the Cold War. By 2003, Turkey had successfully charted a more independent foreign policy and there was greater division within the international community over the second Iraq war. These clear differences in the international system, however, did not have automatic consequences. Not all Turkish leaders in 1991 believed that there was nothing Turkey could do but support the United States. Even the military was willing to defy the ally's pressure. And it would be difficult to argue that Özal was simply acting as a pawn of the United States or that he succumbed to the US pressure against his will. Similarly, in 2003, not all thought that Turkey was 'free' to ignore the request of the United States. Indeed, Erdoğan 
believed it was necessary to support the United States, for Turkey's interests. Thus, the differences in international structures cannot account for the different outcomes and processes of these cases.

Internal structures were very similar across the cases. In the first Iraq war decisions, the Motherland Party was a single party government, controlling a majority of votes in the parliament and all cabinet positions. The cabinet was formed after Özal had left the leadership of the Motherland Party following his election to presidency. Similarly, in the second Iraq war decisions, the cabinet was composed entirely of the AKP deputies and this single party commanded a parliamentary majority. In both cases, there were divisions within the ruling parties: in 1991, some Motherland Party members, led by Mesut Y1lmaz, blamed president Özal for reckless foreign policy behaviour, and in 2003, Bülent Arınç, the speaker of the parliament, and Yalçınbayır, deputy prime minister, opposed the war in general and the US requests from Turkey. In both cases, key bureaucratic and military actors were either pushing for their own policy preference or remained strategically silent. Another important structural constant were the constitutional constraints that were identical across these occasions. Article 92 of the constitution did not allow decisions to be made by the cabinet or by a single leader, and gave the power to the parliament to decide on war powers.

Despite these constraints, Özal did not refrain from pressuring the prime minister and the cabinet or from using his personal influence on certain deputies in the parliament to get a decision to his liking in the first Iraq war. Once the parliament granted the cabinet war powers, Özal conducted all negotiations with the US authorities, shadowing the government. On both occasions for decision, Özal sidelined the traditional policymakers like the military and the ministry of foreign affairs and replaced representatives from these actors with his own advisors and supporters. Unlike previous presidents, Özal went further by interpreting Article 104 of the constitution to its fullest in a way to use the maximum authority given to the president (Kılıç 1990). He was quick to note that, as president, he was the chief of the army, and head of the MGK, and therefore empowered with the mandate of the parliament to authorise Turkish troops when the parliament was in recess. With this, he almost saw himself equal to the prime minister and the cabinet and he acted as if Turkey had a presidential system. In doing so, Özal challenged considerable domestic constraints to secure his preferred outcome in the 1991 Gulf War.

The decision-making process on the first occasion for decision of the second Iraq war was also very complex and involved multiple actors; actions required parliamentary approval but the leadership of the AKP was divided. Erdoğan did not have any official position in the government at the time, but he was nevertheless effectively in charge of the party. Furthermore, Gül did not act as a predominant leader, instead trying to spread the responsibility for the decision. It is telling that the AKP leader Erdoğan did not push hard for approval of the motion either. He held a group meeting on 25 and 26 February, in which he asked party members to vote in 
favour of the bill. He later asked the AKP deputies to write down their preferences on a piece of paper. The results suggested that the majority of the deputies would be voting for the motion, and that the motion would be passed by more than enough votes (Taydaş and Özdamar 2013: 236). This might explain why Erdoğan refrained from taking a group decision at this meeting, which would have required the AKP to vote en bloc on 1 March. The decision was left entirely to the parliament. In this sense, this particular occasion was completely different from the 1991 decision in which Özal displayed a forceful leadership challenging constraints at the risk of creating a domestic political crisis.

As the case studies illustrate, despite similarities in structural factors, the decisions reached in the first and second Iraq war decisions were significantly different from each other. Turkey largely complied with the United States in 1991, while it did so only moderately and belatedly in 2003. These differences cannot be traced easily to different structural pressures or opportunities. Furthermore, both agents who were key in these decisions - Özal and Erdoğan — favoured cooperation with the United States. What is different is how they interacted with the various structures they faced. In what follows below, we examine the personality traits of Turgut Özal and Recep Tayyip Erdoğan to help us understand better how these two leaders reacted to internal and external constraints.

\section{Adding agents' orientations to structures: Özal and Erdoğan's leadership trait analysis}

Table 1 shows scores for Özal and Erdoğan on each of the seven personality traits, as well as the mean scores for the comparison groups composed of world leaders and a smaller set of Middle Eastern leaders. Özal and Erdoğan have very similar scores for belief in ability to control events, in-group bias, distrust of others, and task focus. The traits for which the two leaders differ are conceptual complexity, need for power, and self-confidence. In this section, we focus on the differences in the leaders' traits and explore how they contribute to our understanding of the case studies and the dissimilar processes and outcomes in the foreign policies of these leaders. Due to space considerations, we make reference to the world leaders comparison group; comparisons using the Middle East norming group are almost identical with no significant change in our interpretation of the differences between Özal and Erdoğan. Our aim is to use the LTA traits to provide a reliable, systematic assessment for an understanding of which characteristics of agents affect their interactions with structures and how. Our purpose here is also to evaluate critically the specific traits of LTA for their ability to explain leadership behaviour.

Özal scores higher than Erdoğan (almost one standard deviation above him) on the self-confidence trait. Erdoğan's score (0.36) equals the mean for the world leaders comparison group; Özal (0.45) is almost one standard deviation higher than the world 
Table 1 LTA Profile of Özal and Erdoğan on seven personality traits ${ }^{\mathrm{a}}$

\begin{tabular}{|c|c|c|c|c|}
\hline Personality trait & Özal & Erdoğan & $\begin{array}{c}\text { World mean }[N=284] \\
\text { (standard deviation) }\end{array}$ & $\begin{array}{c}\text { Middle East mean }[N=46] \\
\text { (standard deviation) }\end{array}$ \\
\hline $\begin{array}{l}\text { Belief in ability to } \\
\text { control events }\end{array}$ & 0.35 & 0.37 & $0.35(0.05)$ & $0.33(0.06)$ \\
\hline $\begin{array}{l}\text { Conceptual } \\
\text { complexity }\end{array}$ & 0.66 & 0.58 & $0.59(0.06)$ & $0.56(0.08)$ \\
\hline Distrust of others & 0.09 & 0.11 & $0.13(0.06)$ & $0.16(0.07)$ \\
\hline In-group bias & 0.10 & 0.10 & $0.15(0.05)$ & $0.15(0.06)$ \\
\hline Need for power & 0.22 & 0.31 & $0.26(0.05)$ & $0.27(0.06)$ \\
\hline Self-confidence & 0.45 & 0.36 & $0.36(0.10)$ & $0.31(0.13)$ \\
\hline Task focus & 0.70 & 0.73 & $0.63(0.07)$ & $0.58(0.06)$ \\
\hline
\end{tabular}

${ }^{\mathrm{a}}$ World and Middle East means and standard deviation numbers obtained from Margaret Hermann (email communication). These were calculated from the data created by the ProfilerPlus program (version 5.8.4).

mean. Leaders with high self-confidence have an elevated sense of self-importance and 'are more immune to incoming information from the environment than those with low self-confidence. They are generally satisfied with who they are and are not searching for more material on which to evaluate themselves and their behaviour' (Hermann 2003: 195). Leaders with low self-confidence, on the other hand,

are easily buffeted by the 'contextual winds'. Without a well-developed sense of who they are, such leaders tend to continually seek out information from the environment in order to know what to do and how to confirm to the demands of the circumstances in which they find themselves. [...] To compensate for feelings of inadequacy, these leaders seek to become the agents [...] that can help to enhance their self-confidence. (Hermann 2003: 196)

The difference in Özal and Erdoğan's self-confidence, as measured at the particular time of these decisions, can help explain their dissimilar leadership styles in the cases. Özal's higher self-confidence enabled him to challenge and manipulate domestic constraints, including constitutional limitations on his authority. He also did not hesitate to use his influence directly or indirectly. Sanctions against Iraq were solely and promptly decided by Özal despite the wait-and-see policy of the other actors. He pursued his interests and realised his policy preferences by ensuring the transfer of power to himself, being in direct contact with president Bush, assuming the lead negotiator role, and obtaining legislation that would also give him a lot of leeway in negotiations with the United States. He used his power bluntly and excluded many people from the process to achieve his desired policy outcome. Özal was dismissive towards those who stood in his way, sidelining or eliminating them in the decision-making process. Excluding the ministry of foreign affairs bureaucrats from decision making, he created a domestic political crisis that led to three resignations. Özal's self-confidence can be seen in his firm belief in the 'right thing 
that needed to be done', which was to join the US-led coalition and get Iraq out of Kuwait, and in his adamant pursuit of this policy even at the expense of domestic political relations.

Erdoğan, on the other hand, did not have the high confidence to direct the process at the time. Instead, he let the process unfold itself in the beginning. Unlike Özal, he delegated decision making and negotiations to Gül and Yakış, other people from his party, as well as bureaucrats. Even when he advised the AKP deputies in late February to vote for the US troops deployment in Turkey, Erdoğan did not take a group decision or display a forceful leadership. Similarly, whereas he took charge of the process and acted more decisively and forcefully on the second occasion for decision, he still took into account advice given by other people in the policy-making circles.

Özal and Erdoğan also differ in conceptual complexity. Özal has a higher score (0.66) than Erdoğan (0.58) and is one standard deviation above the mean for the world leaders group, while Erdoğan is one standard deviation below Özal and has almost the same score as the world leaders mean. Conceptual complexity indicates the ability of the leader to differentiate, describe, or discuss other people, places, policies, or ideas in a complex manner. Leaders that have high conceptual complexity see various dimensions of an issue, are more comfortable with uncertainty, and are flexible in their reactions to ideas. Such leaders seek a variety of perspectives and are attuned to contextual information. Leaders who have low conceptual complexity tend to see positions as black-and-white, are unaware of ambiguity in their environment, and are inflexible in their reactions to ideas. Such leaders often act based on their intuition and prefer action to analysis, planning, or an extensive search for information (Hermann 2003).

The differences in complexity between Özal and Erdoğan can be interpreted meaningfully in the cases. Özal's higher complexity may have given him the ability, not just the motivation, to carefully engineer and dominate the decision making. Consistent with conceptually complex leaders, Özal was in constant communication with foreign leaders and he closely monitored the developments in the crisis by seeking first-hand information from his foreign counterparts, especially the US president Bush. Among Turkish leaders, Özal was one of the few who talked with a wide variety of foreign correspondents and journalists on a variety of related topics, such as with experts from OPEC and the Turkish Petroleum Corporation on the effects of crisis for the global oil market. He often explained Turkey's position during the crisis and asked how they saw the events. In his speeches on the crisis, Özal often relied on and disclosed facts about the crisis (e.g. oil prices, new power balance, alliances, trade relations, threat perception) and how other countries in the world, and especially Turkey's Western allies, positioned themselves. He often used factual data to convince the opposition. Erdoğan, on the other hand, was not very successful in manipulating the environment and getting the result he desired, especially on the first occasion for decision. He was also not seeking information actively, especially from 
sources outside of Turkey. Inside the country, he was surprised at the outcome of the parliamentary vote.

The third trait on which Özal and Erdoğan differ is need for power. Özal (0.22) is almost one standard deviation lower than the mean of the comparison group; but Erdoğan's score (0.31) is both above the world leaders average and almost two standard deviations higher than Özal's. According to Hermann (2003), leaders with a high need for power have a strong desire to control or influence others:

They are good at sizing up situations and sensing what tactics will work to achieve their goals. Indeed, they are highly Machiavellian, often working behind the scenes to insure their positions prevail. [...] Leaders high in need for power will test the limits before adhering to a course of action, bartering and bargaining up until the last moment to see what is possible [...]. (ibid., 191).

Leaders who are low in power, on the other hand, are comfortable allowing others to lead and have influence. They put the group's interest before their own and they empower others around them to share responsibility.

Özal's and Erdoğan's scores on this trait do not resonate well in the case studies. Instead, Özal acts much more like a leader with a high need for power, skilfully manipulating the policy-making process, driven by his desire to influence the decisions. Erdoğan, on the other hand does not behave much like a leader with a high need for power. Although he does take greater responsibility and seeks to influence the outcome in the second decision, overall, he does not appear Machiavellian.

Despite the importance of the other LTA traits in previous research on leaders' personalities and foreign policy, this study finds no critical differences between Özal and Erdoğan in terms of their belief in ability to control events (both are around the world leaders mean), distrust (both are close to the mean of the world leaders), ingroup bias (both are one standard deviation below the mean), and task focus (both are one standard deviation higher than the world leaders mean).

Two of the traits that differ between Özal and Erdoğan, self-confidence and conceptual complexity, do help explain these leaders' dissimilar interactions with their structural context in theoretically meaningful ways. This suggests that these traits, and their combinations, deserve more attention in future research. Furthermore, conceptual complexity may relate to leaders' abilities to manipulate constraints as much as it relates to leaders' openness to a variety of perspectives. Finally, Erdoğan's profile may be sensitive to this particular time period, reflecting his high need for power at the time as he learns to control others around him. The time period considered for this study is a peculiar one as he was just elected to a national political office and right after his domestic political ban on him. This is consistent with personality theory that stresses the interaction between the agent and the context: as the context changes, individuals may adapt to new situations within certain parameters of their personality traits. Some leaders, however, such as Erdoğan, are much more likely to be sensitive to contextual changes and learning opportunities 
than others (Hermann 2003). Specifically, we would also predict that his selfconfidence would increase over his tenure in office. As a result, he would become more dominant in the decision-making process over time.

Indeed, a key difference between Özal and Erdoğan is their levels of experience. Özal was a much more seasoned politician during the decision making for the first Iraq war; Erdoğan was only just coming to power in a national office during the decision making for the second Iraq war. Erdoğan's lower scores for self-confidence and complexity and his higher need for power may be related to his lack of experience at this time. This does not mean, however, that Erdoğan's personality profile is merely a reflection of his new role - leaders' personalities do change over time (Renshon 2008), especially for leaders more sensitive to their environments (Hermann 2003). Furthermore, not all new leaders are low in self-confidence and complexity and high in need for power - leaders vary in terms of how they respond to experience. Finally, other research suggests that experience may not always matter. Dyson and Preston (2006) find that leaders are not more likely to base analogies in their own experiences, but experienced and inexperienced leaders both refer to generally available knowledge. They claim that 'the availability of an analogy is impacted less by the event being personally experienced than was previously thought' (ibid.: 283). Likewise, Hermann et al. (2001: 100) note that leaders may challenge constraints in domestic or international policy both when they are experienced and when they have little experience.

Hermann (1980) has suggested that experience acts as an intervening variable. Leaders with more experience may rely on their background and thus their personalities and predispositions matter less than those of leaders who are new to the position. We do not see this dynamic in the case studies. While Erdoğan's lack of experience may be reflected in his traits at the time, Özal's traits do not seem to be muffled by his experience. Quite the contrary, Özal's considerable experience seems to interact with his predispositions as he skilfully manipulated the process and challenged constraints.

To unpack further the effects of the different levels of experience for these two leaders, we examined the leaders' personality characteristics at alternative points in their career. When we compare 'Özal the inexperienced' (with data from the 1980s till his presidency in 1989) with 'Özal at the time of the Iraq case', we find little difference in the key traits of conceptual complexity and self-confidence. ${ }^{9}$ When we compare 'Erdoğan the experienced' (with data from August 2007 to June 2013) with 'Erdoğan at the time of the Iraq case', we also find little difference (and no statistically significant difference) in the key traits of conceptual complexity and self-confidence. ${ }^{10}$ The differences in these two leaders' levels of experience, although important, cannot account easily for their different styles in the Iraq cases. Moreover, just comparing the differences in these leaders' levels of experience would tell us little about how experience matters. LTA allows us to focus on how experience might be evident (by identifying need for power, complexity, and confidence) and the 
case studies reveal how these differences influenced the process and outcome of these decisions.

\section{Conclusions}

According to a prominent volume on operational code research (Schafer and Walker 2006), it is the intersection of agent and structure that foreign policy researchers should focus on, for future work here will yield the most returns. Other theories support this idea, but few authors address directly the orientation of agents to structural constraints and most of our understanding of security policy privileges decidedly the structural explanations in systemic, institutional and cultural forms. This study engaged this topic directly by examining how leaders interact with their institutional, political and situational contexts and by tracing the effects of leaders' personalities.

Despite similar or indeterminate structural constraints, Turkey's 1991 and 2003 Iraq war decisions differed significantly in terms of process and outcome. We argue that the difference in the outcomes cannot be explained by structural constraints alone. By means of process-tracing, we demonstrated variation in leaders' orientations to and interactions with structures. Working under very similar contextual constraints, Özal and Erdoğan used different tactics and strategies. For example, whereas Özal managed to dictate his preferences and utilised effectively his leverage over the prime minister and the cabinet, Erdoğan allowed the process to unfold and, in the end, was not always able to secure his preferred outcome. Indeed, Erdoğan was pushed and pulled by the different preferences of the United States, the military, and his own party.

The differences in Özal's and Erdoğan's self-confidence and conceptual complexity, we conclude, underpin their approaches in these cases. The content analytic LTA framework provides a valuable tool for specifying the characteristics of agents and how they relate to their contexts. The combination of LTA with structured-focused and process-tracing comparative case studies is an especially fruitful approach to study the nuanced agency - structure interaction. Overall, the differences in how these leaders interacted with their decision-making environments and the dissimilar decision outcomes in similar situations support the view that a given structure may be interpreted and acted upon differently by leaders who may have different styles and traits and that leaders are not equally constrained or empowered by constraints.

Our examination of Özal and Erdoğan is an important contribution as it adds theoretically to the study of leaders and international politics and empirically to our understanding of Turkish leaders and Turkish foreign policy. The choices of Turkey, as a strategic ally to the United States, as a member of NATO, and as an increasingly important economic and regional power, can have a major impact in international politics. Although they often have to coordinate policy choices with the military, coalition partners, and international actors, Turkish prime ministers and presidents have considerable influence in foreign policy decision making. How they see the 
world, how they choose to react to challenges, and what informs their preferences are significant to an understanding of Turkish foreign policy. Scholars of Turkish foreign policy are not alone in continuing to privilege structural factors over agents; leaders characteristics are under-theorised and rarely investigated in general international relations research. Yet, a complete understanding of international politics and decision-making processes and outcomes requires serious theoretical and empirical attention to how characteristics of agents shape leaders' orientations to systemic, institutional, and situational constraints. LTA and other approaches to political personalities (e.g. operational code research and cognitive mapping) offer conceptual grounding and reliable methods for capturing this relationship.

\section{Acknowledgements}

The authors gratefully acknowledge that this research was supported by a TUBITAK Evrena grant (110K112). We would like to thank Margaret G. Hermann and Ryan Beasley for their helpful comments, Michael Young at Social Science Automation for making ProfilerPlus available to us, as well as Hanneke Derksen. An earlier version of this paper was presented at the International Studies Association Convention in 2010; we would like to thank our discussant Akan Malici for his helpful comments. Finally, we extend our thanks to three anonymous reviewers and the journal's editorial team for their constructive feedback.

\section{Notes}

1 For more on the importance of prime ministers and presidents in Turkish foreign policy, see Özcan (2008), Robins (2003b) and Hale (2002).

2 SSA is headed by Michael R. Young; Margaret Hermann was a co-founder in 1997. In ProfilerPlus, SSA converted Hermann's Leadership Traits Analysis and Steven Walker's Operational Code Analysis hand-coding practices into automated coding (www.socialscience.net).

3 See Hermann (2003) on how scores are calculated on each personality trait.

4 Erdoğan's word count is lower because he did not have an official role in decision-making processes. This limited his public, spontaneous statements on Iraq. However, by all accounts (including interviews of several high-level policymakers from this case), Erdoğan was actively involved in decision making, especially concerning the decisions that were very critical for the negotiations and the case.

5 For discussions and examinations of these issues, see Dille and Young (2000), Marfleet (2000), Schafer (2000), Schafer and Crichlow (2000), Schafer and Walker (2006), Renshon (2008), Renshon (2009), and Schafer and Crichlow (2010).

6 According to Mehmet Keçeciler, this decision had to be taken in any case because of the UN Resolution. Indeed, the next week the US secretary of state James Baker was visiting Turkey. The decision was announced right before Baker's visit enhanced Turkey's negotiating position vis-à-vis the United States as the latter saw this as an important gesture in their partnership (authors' interview with minister Mehmet Keçeciler, July 2013).

7 In 1998, after reciting a poem that allegedly incited religious hatred, Erdoğan was imprisoned and banned from running for political office.

8 Authors' interview with Yaşar Yakış, August 2013. 
9 The $t$-test score for conceptual complexity for Özal was $t(71)=0.784$ (not significant) and for selfconfidence $t(70)=0.377$ (not significant). No other trait had a statistically significant difference across the time periods for Özal.

10 The t-test score for conceptual complexity for Erdoğan was $t(120)=0.508$ (not significant) and for confidence it was $t(114)=0.532$ (not significant). The only trait that was statistically significantly different across time was task orientation, indicating that Erdoğan became less problem-focused during his second term with $t(121)=-3.35(p<0.005)$.

\section{References}

Balbay, Mustafa (2004) Irak Bataklığında Türk-Amerikan Illişkileri, İstanbul: Cumhuriyet Yayınları.

Bennett, Andrew (2010) 'Process Tracing and Causal Inference', in Henry Brady and David Collier, eds, Rethinking Social Inquiry: Diverse Tools, Shared Standards, 207-20, Lanham, MD: Rowman and Littlefield.

Berger, Thomas U. (1998) Cultures of Antimilitarism: National Security in Germany and Japan, Baltimore, MD: Johns Hopkins University Press.

Bölükbaşı, Deniz (2008) 1 Mart Vakası: Tezkere Krizi ve Sonrası, İstanbul: Doğan Egmont Yayıncılık ve Yapımcilık.

Bueno de Mesquita, Bruce, Alastair Smith, Randolph M. Siverson and James D. Morrow (2003) The Logic of Political Survival, Cambridge, MA: MIT Press.

'Bush'tan Özal'a: Boru Hattını Kapatın' (1990) Cumhuriyet (4 August).

Carlsnaes, Walter (1992) 'The Agency-Structure Problem in Foreign Policy Analysis', International Studies Quarterly 36(3): 245-70.

Checkel, Jeffrey T. (2008) 'Process Tracing', in Audie Klotz and Deepa Prakash, eds, Qualitative Methods in International Relations: A Pluralist Guide, 114-28, New York: Palgrave Macmillan.

Chiozza, Giacomo and Hein E. Goemans (2011) Leaders and International Conflict, Cambridge: Cambridge University Press.

Department of Defence (1992) Final Report to the Congress: 22.

Department of Public Information of the United Nations (1990) UN Security Council Resolution No. 660: 167, http://www.un.org/en/hq/dpi/.

Dessler, David (1989) 'What is at Stake in the Agent-Structure Debate?' International Organization 43(3): $441-73$.

Dille, Brian and Michael D. Young (2000) 'The Conceptual Complexity of Presidents Carter and Clinton: An Automated Content Analysis of Temporal Stability and Source Bias', Political Psychology 21(3): 587-95.

Dyson, Stephen B. (2006) 'Personality and Foreign Policy: Tony Blair's Iraq Decisions', Foreign Policy Analysis 2(3): 289-306.

Dyson, Stephen B. and Thomas Preston (2006) 'Individual Characteristics of Political Leaders and the Use of Analogy in Foreign Policy Decision Making', Political Psychology 27(2): 265-88.

Efegil, Ertan (2002) Körfez Krizi ve Türk Dış Politikası Karar Verme Modeli, İstanbul: Gündoğan Yayınları.

Finnemore, Martha and Kathryn Sikkink (1998) 'International Norm Dynamics and Political Change', International Organization 52(4): 887-918.

George, Alexander L. and Timothy J. McKeown (1985) 'Case Studies and Theories of Organizational Decision Making', in Robert Coulam and Richard Smith, eds, Advances in Information Processing in Organizations, 21-58, Greenwich, CT: JAI Press.

Gerring, John (2007) 'Is There a (Viable) Crucial-Case Method', Comparative Political Studies 40(3): 231-53. 
Giddens, Anthony (1984) The Constitution of Society: Outline of the Theory of Structuration, Cambridge: Polity.

Gilpin, Robert (1983) War and Change in World Politics, Cambridge: Cambridge University Press.

Goldgeier, James M. (1997) 'Psychology and Security', Security Studies 6(4): 137-66.

Gözen, Ramazan (2005) 'Causes and Consequences of Turkey's Out-of-War Position in the Iraq War of 2003', Turkish Yearbook of International Relations 36: 73-99.

Hale, William M. (2000) Turkish Foreign Policy, 1774-2000, Portland: Frank Cass.

Hänggi, Heiner (2004) 'The Use of Force Under International Auspices: Parliamentary Accountability and "Democratic Deficits", , in Hans Born and Heiner Hänggi, eds, The 'Double Democratic Deficit': Parliamentary Accountability and the Use of Force under International Auspices, 3-16, Aldershot: Ashgate.

Hermann, Margaret G. (1980) 'Explaining Foreign Policy Behavior Using the Personal Characteristics of Political Leaders', International Studies Quarterly 24(1): 7-46.

Hermann, Margaret G. (1984) 'Personality and Foreign Policy Decision Making: A Study of 53 Heads of Government', in Donald A. Sylvan and Steve Chan, eds, Foreign Policy Decision-Making:Perceptions, Cognition, and Artificial Intelligence, New York: Ashgate, Praeger.

Hermann, Margaret G. (1987) Handbook for Assessing Personal Characteristics and Foreign Policy Orientations of Political Leaders, Columbus, OH: Mershon Center, Ohio State University.

Hermann, Margaret G. (2001) 'How Decision Units Shape Foreign Policy: A Theoretical Framework', International Studies Review 3(2): 47-81.

Hermann, Margaret G. (2003) 'Assessing Leadership Style: A Traits Analysis', in Jerrold M. Post, ed., The Psychological Assessment of Political Leaders: With Profiles of Saddam Hussein and Bill Clinton, 178-215, Ann Arbor: University of Michigan Press.

Hermann, Margaret G. and Charles W. Kegley Jr. Charles W. (1995) 'Rethinking Democracy and International Peace: Perspectives from Political Psychology’, International Studies Quarterly 39(4): 511-34.

Hermann, Margaret G., Thomas Preston, Baghat Korany and Timothy M. Shaw (2001) 'Who Leads Matters: The Effects of Powerful Individuals', International Studies Review 3(2): 83-132.

Journal of Proceedings of the Parliament (TBMM Tutanak Dergisi) (1990) Term 18, Vol. 47/1, Legislation Year: 4 (1 September).

Kaarbo, Juliet (2012) Coalition Politics and Cabinet Decision Making, Ann Arbor: University of Michigan Press.

Kapsis, James E. (2006) 'The Failure of US-Turkish pre-Iraq War Negotiations: An Overconfident United States, Political Mismanagement, and Conflicted Military', Middle East Review of International Affairs 10(3): 33-45.

Keohane, Robert O. and Joseph Nye (1977) Power and Interdependence: World Politics in Transition, Cambridge, MA: Harvard University Press.

Kesgin, Baris and Juliet Kaarbo (2010) 'When and How Parliaments Influence Foreign Policy: The Case of Turkey's Iraq Decision', International Studies Perspectives 11(1): 19-36.

Kılıç, Altemur (1990) 'Editorial', Tercüman (8 December): 1.

Kille, Kent J. and Roger M. Scully (2003) 'Executive Heads and the Role of Intergovernmental Organizations: Expansionist Leadership in the United Nations and the European Union', Political Psychology 24(1): 175-98.

Krasner, Stephen D. ed. (1983) International Regimes, Ithaca: Cornell University Press.

LeBlang, David and Steve Chan (2003) 'Explaining Wars Fought by Established Democracies: Do Institutional Constraints Matter?' Political Research Quarterly 56(4): 385-400.

Lobell, Steve E., Norrin M. Ripsman and Jeffrey W. Taliaferro, eds, (2009) Neoclassical Realism, The State, and Foreign Policy, Cambridge: Cambridge University Press.

Mahoney, James (2004) 'Structured, Focused Comparison', in Michael Lewis-Beck, Alan E. Bryman and Tim Futing Liao, eds, Encyclopedia of Social Science Research Methods, 1099-100, Thousand Oaks: Sage. 
Makovsky, Alan (1999) 'The New Activism in Turkish Foreign Policy', SAIS Review 19(1): 92-113.

Makovsky, Alan and Sabri Sayarı, eds, (2000) 'Introduction', in Turkey's New World: Changing Dynamics in Turkish Foreign Policy, 1-8, Washington DC: Washington Institute for Near East Policy.

Marfleet, B. Gregory (2000) 'The Operational Code of John F. Kennedy During the Cuban Missile Crisis: A Comparison of Public and Private Rhetoric', Political Psychology 21(3): 545-58.

Mintz, Alex and Karl DeRouen (2010) Understanding Foreign Policy Decision-Making, New York: Cambridge University Press.

Oğuz, Mustafa (2005) 'Conflict within the Turkish Foreign Policy Decision-Making Mechanism: The Cases of the Gulf War and the USA Military Intervention in Iraq', Unpublished MA thesis, Sabanc1 University: İstanbul.

Oran, Baskın (2001) Türk Dış Politikası: Kurtuluş Savaşından Bugüne Olgular, Belgeler, Yorumlar, Istanbul: İletişim Yayınları.

Owen, John M. (1994) 'How Liberalism Produces Democratic Peace', International Security 19(2): $87-125$.

Özcan, Mesut (2008) Harmonizing Foreign Policy: Turkey, The EU and The Middle East, Aldershot: Ashgate.

Özdamar, Özgür and Zeynep Taydaş (2012) 'Turkey', in Richard Sobel, Peter Furia and Bethany Barratt, eds, Public Opinion and International Intervention: Lessons from the Iraq War, 201-18, Dulles, VA: Potomac Books.

Özkeçeci-Taner, Binnur (2005) 'The Impact of Institutionalized Ideas in Coalition Government Foreign Policymaking: Turkey as an Example, 1991-2002', Foreign Policy Analysis 1(3): 249-78.

Özkeçeci-Taner, Binnur (2009) The Role of Ideas in Coalition Government Foreign Policymaking: The Case of Turkey Between 1991 and 2002, Dordrecht: Republic of Letters Publishers.

Palmer, Glenn, Tamar R. London and Patrick M. Regan (2004) 'What's Stopping You?: The Sources of Political Constraints on International Conflict Behavior in Parliamentary Democracies', International Interactions 30(1): 1-24.

Pertman, Adam (1990) 'Baker in Turkey to Seek Bases, Deliver Kuwait Offer', The Boston Globe (9 August): 6.

Renshon, Jonathan (2008) 'Stability and Change in Belief Systems: The Operational Code of George W. Bush from Governor to Second-term President', Journal of Conflict Resolution 52(6): 820-49.

Renshon, Jonathan (2009) 'When Public Statements Reveal Private Beliefs: Assessing Operational Codes at a Distance', Political Psychology 30(4): 649-61.

Robins, Philip (2003a) 'Confusion at Home, Confusion Abroad: Turkey Between Copenhagen and Iraq', International Affairs 79(3): 547-66.

Robins, Philip (2003b) Suits and Uniforms: Turkish Foreign Policy Since the Cold War, Seattle: University of Washington Press.

Russett, Bruce M. (1993) Grasping the Democratic Peace: Principles for a Post-Cold War, Princeton: Princeton University Press.

Schafer, Mark (2000) 'Issues in Assessing Psychological Characteristics At a Distance', Political Psychology 21(3): 511-27.

Schafer, Mark and Scott Crichlow (2000) 'Bill Clinton's Operational Code: Assessing Source Material Bias', Political Psychology 21(3): 559-71.

Schafer, Mark and Scott Crichlow (2010) Groupthink vs. High-Quality Decision Making in International Relations, New York: Columbia University Press.

Schafer, Mark and Stephen G. Walker, eds, (2006) 'Operational Code Analysis at a Distance: The Verbs in Context System of Content Analysis', in Beliefs and Leadership in World Politics: Methods and Applications of Operational Code Analysis, 25-51, New York: Palgrave Macmillan.

Taydaş, Zeynep and Özgür Özdamar (2013) 'A Divided Government, an Ideological Parliament, and an Insecure Leader: Turkey's Indecision about Joining the Iraq War', Social Science Quarterly 94(1): 217-41. 
Wagner, Wolfgang (2006) 'The Democratic Control of Military Power Europe', Journal of European Public Policy 13(2): 200-16.

Waltz, Kenneth (1979) Theory of International Politics, Reading, MA: Addison-Wesley.

Wendt, Alexander (1999) Social Theory of International Politics, Cambridge and New York: Cambridge University Press.

Yanatma, Servet (2008) '1 Mart'ın Üzerinden Beş Yıl Geçti; Ancak Muhasebesi Netleşmedi', Zaman (1 March).

Yetkin, Murat (2003) 'Hükümet Krizi', Radikal (2 March).

Yetkin, Murat (2004) Tezkere: Irak Krizinin Gerçek Öyküsü, İstanbul: Remzi Kitabevi.

\section{About the authors}

Esra Cuhadar is Assistant Professor in the Department of Political Science at Bilkent University, Ankara, Turkey. She was a Fulbright Research Scholar at the Fletcher School of Law and Diplomacy at Tufts University in 2011/2012. Her research appears in International Negotiation, Journal of Peace Research, Mediterranean Politics, International Studies Perspectives, Turkish Studies, and Perceptions, as well as in various book chapters.

Juliet Kaarbo is Senior Lecturer in Politics and International Relations at the University of Edinburgh. Her research interests include foreign policy decision making, and the role of leader personalities, institutional constraints, and small group dynamics in foreign policy. Her work has appeared in several journals, most recently in Cooperation and Conflict, International Studies Review, and Foreign Policy Analysis. Also recently, she has published Coalition Politics and Cabinet Decision Making: A Comparative Analysis of Foreign Policy Choices (University of Michigan Press).

Baris Kesgin is Assistant Professor in Political Science at Susquehanna University, USA. He specialises in foreign policy analysis and political leadership — in particular of Israel and Turkey. His research (with Juliet Kaarbo) on the role of parliaments in foreign policymaking appeared in International Studies Perspectives. Recently, he has published articles on former prime minister of Turkey Tansu Ciller's leadership traits and foreign policy in Perceptions, and on profiles of Turkish prime ministers since 1991 in Turkish Studies.

Binnur Ozkececi-Taner is Associate Professor in Political Science at Hamline University, USA. Her research focuses on Turkish foreign policy analysis, foreign policy decision making, and coalition government politics. She has published The Role of Ideas in Coalition Government Foreign Policymaking: The Case of Turkey between 1991 and 2002 (2009, Brill/Republic of Letters). Her most recent publications appear in Perceptions: A Journal of International Affairs and Turkish Politics. 